\title{
The Proposed Community Property Bills
}

$\mathrm{T}$ HE Community Property bills ${ }^{1}$ before the California legislature are worthy of special attention by the legal profession, not only for their practical importance in the business world, but as marking a significant advance in the historical development of property relations between spouses. The agitation for change comes fron the growth of the feminist movenient in recent years, the growth of a political classification based on sex.

Former changes have come about from different motives. For example, wealthy men of property have wanted to provide for their daughters and niake sure that the property would not be controlled or wasted by the husbands the daughters might n1arry. ${ }^{2}$ This result has been accomplished satisfactorily in almost every nodern jurisdiction. Accordingly there has not been a great deal of change in the property laws relating to married women except what has been brought about by the agitation of the feminist movement. This has resulted, however, in creating a certain atmosphere of bias and prejudice, obscuring the real issues. The present law of California, for example, is attacked on the ground that it prevents married women from controlling their own property. This, of course, is not entirely true. It is perfectly competent for man and woman, either before, at or after niarriage, to enter into a contract regulating their property relations in any way they may see fit. ${ }^{3}$ They have just the same powers in this regard as two men. It is, of course, true that after marriage, when the community rights of the husband have become vested, he cannot be compelled to relinquish those rights, but every woman has the power before marriage to insist upon a satisfactory arrangement for the property to be subsequently acquired by either. The law forbids nothing; it siniply covers the cases where the parties have not provided otherwise.

Another charge is that the law constitutes an unjust discrimination against wonen. There was doubtless some justification

1 Assembly Bills, Nos. 696, 698, introduced by Miss Broughton; Senate Bills 470, 471, introduced by Senator Thompson. Assembly Bills 697,200 , and Senate Bills 472,522,680, also have some bearing on the matter.

2 Dicey, Law and Opinion in England, p. 383.

3 Cal. Civ. Code, § 159. 
for this in the early stages of legal development. A woman $^{4}$ could not be the head of the family, but her position in the family was not materially different from that of the men, especially the younger men; all were equally in the power of the head of the family. The decay of the family as an important social, legal and political unit resulted in the emancipation of the men from guardianship, and somewhat more tardily the women, so that it became possible to say of the England of the fourteenth century: "Private law with few exceptions puts women on a par with men." "As regards private rights women are on the same level as men, though postponed in the canons of inheritance; .... We have been speaking of women who are sole, who are spinsters or widows. Women who have husbands are in a different position". ${ }^{5}$ In France we find the same thing: "The influence of the Roman Law and the Christian ideas, the disorganization of the family group, the interference of the State within the circle of private interest, brought about the gradual ennancipation, here slow, there more rapid, of unmarried women. It is thus that among the Franks we have been justified in asking if as early as the barbarian period the guardianship of women had not disappeared."' In Germany traces of this guardianship remained, but were all removed in the nineteenth century. ${ }^{7}$ The law of California, as might be expected, does not differ in this respect. There is absolutely no property disqualification against women as such. An unmarried woman or widow has and has had during the entire history of California just the same property rights and other private law rights as a man. The problem, therefore, is not one of equality between the sexes, but the proper adjustment of the property rights between husband and wife. Even in the sphere of husband and wife it cannot be said fairly that on the whole the laws were deliberately made by husbands to take advantage of wives. Injustice there certainly was.

Huebner, History of Germanic Private Law, Constitutional Legal History Series, p. 61; Brissaud, History of French Private Law, Continental Legal History Series, p. 221, and see Bryce, Marriage and Divorce Select Essays in Anglo-American Legal History, Vol. 3, p. 782.

5 Pollock and Maitland, History of English Law, Vol. 1, pp. 482, 485 ; vol. 2 , p. 437 .

6 Brisssaud, History of French Private Law, Continental Legal History Series, p. 225.

$\tau$ Huebner, History of Germanic Private Law, Continental Legal History Series, p. 68; Progress of Continental Law in the 19th Century, Continental Legal History Series, p. 193. 
"At the common law, a wife's corporeal chattels passed to her husband absolutely. $\mathrm{He}$ could, if he pleased, enforce, or reduce into possession, her choses in action; but, if he did not do so, and predeceased her, they survived to her. By virtue of this doctrine, he could also collect the rents of her lands from the day of the marriage; but he did not obtain a 'real' interest, or estate, in her lands of inheritance, until the birth of issue by her capable of inheriting. On the birth of such issue, however, if the wife were actually seised of a present estate of inheritance, the seisin passed to the husband for his life, under the name of 'tenant by the curtesy.' The wife, from the day of the marriage, ceased to have any contracting power; her contracts, if they were valid at all, were only valid as the contracts of her husband, and he alone (if any one) was liable on them. $\mathrm{He}$ was also liable for her ante-nuptial debts, whether he received any property with her, or not; and for her torts committed before or during the marriage. In a word, her legal personality (but not that of her heirs) was merged in his; to such an extent that, though the husband could not affect the inheritance of her land, yet the wife could not dispose of it otherwise than by fine. She had no power at all to make a will without his consent; and he could not even authorize her to make a will of land."8

By way of compensation the wife obtained on the death of the husband a life estate in one-third of all the lands of which he had been seised during the marriage. It is evident that much injustice was possible under the English common law.

"I remember a case some years ago of a sailor who made his will in favor of a woman with whom he cohabited, and afterwards went to the West Indies and married a woman of considerable substance; and it was held, notwithstanding the hardship of the case, that the will swept away from the widow every shilling of the property; for the birth of a child must necessarily concur in order to constitute an implied revocation."

Hard as the case was, it was the logical consequence of what Brissaud characterizes as the absurd logic which organized the entire system of property between spouses as a function of the incapacity of the married woman. This theory was carried to the logical extreme whether it injured the husband or the wife. The husband obtained a power over the wife's property, but he also

8 Jenks, Short History of English Law, p. 222; Jones' Blackstone, p. 1300 , n.

${ }_{9}$ Lord Ellenborough, in Doe d. White v. Barford (1815) 4 M. \& S. 10, 105 Eng. Rep. R. 739. 
became responsible for her debts before marriage. The reader will recall Thackeray's story of the Fatal Boots in the Yellow Plush Papers. The usurious young hero of that romance was wooed and won by a lady reputed to possess the wealth of a Croesus. After the marriage her wealth was discovered to be a negative quantity, consisting entirely of debts and the husband found himself in prison and his entire inheritance swept away to pay her creditors. It is of course familiar that the English courts of equity made it possible to convey property to a inarried woman so that she might exercise control of it.

"Let it, however, be noted, that the aim of the Court of Chancery had throughout been not so much to increase the property rights of married woinen generally, as to enable a person (e.g., a father) who gave to, or settled property upon a woman to ensure that she, even though married, should possess it as her own, and be able to deal with it separately from, and independently of, her husband, who, be it added, was, in the view of equity lawyers, an 'eneny' against whose exorbitant common law rights the Court of Chancery waged constant war."10

Further to carry out this protection the control of the married woman over property was limited by means of the clause restraining anticipation.

"If it was subject to such restraint,she was during coverture unable to exercise the full rights of an owner, but in compensation she was absolutely guarded against the possible exactions or persuasions of her husband, and received a kind of protection which the law of England does not provide for any other person except a married woman."11

By modern statutes the English law has come to this practically: that each spouse keeps what he or she has or acquires By custoin, however, much of the property which is held by married woinen is still held by thein under conveyances containing the restraint on anticipation. Dower has become nothing more than a right of the widow to succeed to the real property of which the husband dies seised, unless he has made some other disposition of it by will or otherwise. This is a system of pure equahty and is very much like the Roman law. By the early Roman law "whatever the wife acquires she acquires for her husband and any property she may have at the time of her marriage

10 Dicey, Law and Opinion in England, p. 376.

11 Id., p. 379. 
passes in its entirety (per universitatem) to her husband by the necessary operation of law."12 Under the developed Roman law, however, marriage had in general no effect upon the property rights of the spouses. Each spouse kept and managed the property he or she had at marriage as well as that acquired afterwards. To a certain extent there was a limitation by the duty of the husband to maintain the wife and the custom of making a contribution to the husband (the dos). As it finally worked out the husband in the end got nothing more than the right to manage this dotal property and enjoy the profits of it. ${ }^{13}$

In the early German law it is possible to find every conceivable combination. In the early law there was the dowry or marriage portion given with the wife, either by the house of her parents or by the household community to which she belonged; and dower, a gift by the husband to the wife, developed out of the purchase price formerly paid to the family. In course of time the old "morning gift" also became merged with the dower. The husband had the administration of all this property. The later Germanic developments were along the line of two systems, a system without community and a system of community.

In the system without community, known sometimes by the misleading term of "administrative community", better, perhaps, called "administrative union", the property of the wife and husband were separate; what the husband had and acquired was his and what the wife had and acquired was hers, but the whole was subject to the control and administration of the husband. Usually he could dispose of the movables without the wife's consent, but her consent was generally required for the immovables. On death the property was divided according to its ownership. ${ }^{14}$ This was a simple system, well adapted to rural conditions where most of the capital was in land. Under urban conditions such a system affords very little protection for the wife, for she gets no rights in the husband's acquisitions, which usually come in the form of movables as a result of commercial activity. ${ }^{15}$

There were also various systens of marital community, differing, however, from the administrative union less than might

12 Sohm's Institutes of Roman Law, Ledlie (3rd ed.) p. 459.

13 Id., p. 471.

It Huebner, History of Germanic Private Law, Chap. XI.

15 Id., p. 630 . 
be expected. Sometimes all the property at marriage was put in the community, sometimes only a portion. But, as in the administrative umion, the husband had the entire administration of this joint property, although as a rule the wife's consent was required to dispose of immovables. On death of one of the spouses the collective estate was divided between the survivor and the heirs of the decedent, the wife receiving one-third or one half, according to the custom of the particular place, and depending in part on whether there were children surviving. The control and power of the wife under this system and her protection were no greater than under the systems without community. The particular advantage, however, was that on the death of the husband she procured a portion of the acquisitions during the marriage.

The modern law of Germany did not attempt to supersede all the diverse and complex systems; the administrative union is assumed if nothing else is agreed on, but other systems are defined and regulated and the parties may make other arrangements by contract. Under the administrative union the wife's property is divided into privileged and non-privileged. The privileged property consists of: "(1) things intended exclusively for the wife's personal use, more particularly clothes, personal ornaments and appliances for the wife's work; (2) property acquired by the wife's work or by any trade carried on by her independently of her husband; (3) property declared to be privileged property by the marriage contract; (4) property given as privileged property by a testator or donor; (5) property acquired by virtue of a right included in the privileged property or by way of substitution for any destroyed, damaged or withdrawn objects previously forming part of the privileged property, or by virtue of any act-in-the-law having reference to the privileged property." ${ }^{16}$ All of the wife's property not privileged is put in the non-privileged class. The wife has complete powers of disposition over her privileged property, but as regards the nonprivileged the husband is entitled to take possession of it, manage it, and dispose of money or other consumable things. The wife, therefore, has very hittle control of the non-privileged property, unless the husband consents or in some cases ratifies her act. The husband has the usufruct of the non-privileged property and applies it to the expenses of management of the joint house-

${ }^{26}$ Schuster, The Principles of German Civil Law, p. 500. 
hold. The wife has an action for security to protect her nonprivileged property and the husband's creditors have no right against the wife's property, either privileged or non-privileged. At death the survivor takes his property and the next of kin of the deceased spouse receive the decedent's property unless otherwise provided by will.

While the German law has favored the adininistrative union, the French law extends similar favor to the community system. The coinmunity in the French law consists of:

"1. All the movables which husband and wife possess on the day of their marriage, and also all the inovables which they may acquire during marriage, either under a succession or by gift inter vivos; unless the donor has expressed a contrary intention.

" 2 . All the produce, revenues, interest or arrears of every kind which fell due, or have been received during marriage from property which belonged to either husband and wife at the time of their inarriage, or from property which they fell into during the marriage, whether as heirs or otherwise.

"3. All the movables purchased during marriage."17

The husband has the sole managenent of the property of the community. He also has the management of all his wife's separate property. At death the survivor and the heirs of the decedent each take out their separate property and the community is divided equally. The parties may change this community system in many ways by contract before marriage, but not by any agreement after. To a limited extent the wife has obtained rights in her earnings. ${ }^{18}$

In the Spanish law the community property of husband and wife consists of :

"1. All property of whatever nature, which the spouses acquire by their own labor and expense (onerous title). This includes property acquired during the marriage at the expense of the comnunity.

"2. Property acquired jointly in the name of both husband and wife.

"3. The fruits of income of individual property of husband and wife, or of the coininunity property."19

17 French Civil Code, Blackwood-Wright, § 1401.

18 Progress of Continental Law in the Nineteenth Century, Continental Legal History Series, p. 209.

19 Walter Loewy, 1 California Law Review, 39. 
The husband manages the property and on the death of one of the spouses an equal division of the estate takes place between the survivor and the heirs of the deceased spouse. The present law of California is very similar to the Spanish law, differing from it in that the income of separate property in California continues to be separate, and on the death of the wife the entire community property goes to the husband without administration. Subject to some minor exceptions the wife has no vested right in the community property during the marriage. Her interest has been termed inchoate, a mere expectancy, which she takes by succession and not as co-owner. ${ }^{20}$

The proposed amendments to the California law are intended to accomplish three things: (1) to give the wife an equal share in the nianagement and control of the community property; (2) to give her the right to dispose by will of her share of the community property; (3) to give her the entire conmunity property on the death of her husband, unless he has disposed of his half by will. ${ }^{21}$ What are the reasons for the change?

${ }_{20}$ Dargie v. Patterson (1917) 176 Cal. 714, 169 Pac. 1360; Spreckles v. Spreckels (1916) $172 \mathrm{Cal}$. 775, $158 \mathrm{Pac}$. 537; Spreckels y. Spreckels (1897) 116 Cal. 339, 48 Pac. 228, 36 L. R. A. 697, 58 Am. St. Rep. 170.

21 "Section 1. Section one hundred sixty-four of the Civil Code is hereby amended to read as follows:

"164. All other property acquired after marriage by either husband or wife, or both, is community property, and husband and wife have, each, the same and equal right, title and interest in and to such community property. In cases where a married wonran has conveyed, or shall hereafter convey, real property which she acquired prior to May 19,1889 , the husband of such married woman, and his heirs and assigns, shall be barred from commencing or maintaining any action to show that said real property was community property, or to recover said real property, unless such action is commenced within one year from and after the filing for record in the recorder's office of the instrument conveying such real property.

"Sec. 2. Section one hundred seventy-two of the Civil Code is hereby amended to read as follows:

"172. Each spouse has the same and equal rights in and to the management, control, conveyance and disposition of the community property; but neither spouse may, without the written consent of the other lease, convey, encumber or dispose, except by testamentary disposition, of only his or her individual interest in the community property, or in any portion thereof, to a third person; and neither spouse shall, without the written consent of the other, have any power to make a gift of any of the community property, or to dispose, except by testamentary disposition of any of the community property without a valuable consideration therefor. Each spouse is presumed to be the agent of the other for the purpose of managing, controlling, conveying or encumbering community personal property which is in his or her immediate possession or control; and this presumption is conclusive in favor of a purchaser, pledgee, or mortgagee, in good faith and for fair value; but neither spouse may, without the written consent of the other, sell, convey or encumber the household furniture used by the family or the wearing 
Would it not be more in accord with the principles of equality between the sexes to adopt the English law of the separation of estates? That is absolute equality or nearly so, the property rights of the spouses continumg just as if they were not married. To bring about this system in California all that would be necessary would be to abolish the present community system and allow the wife to control her own earnings Against this, the proponents of the measure contend that such equality is theoretical, that it does not correspond with the actual condition of things in society; that it might accord with some future state in which married women, after achieving civil and political equality, had also acquired economic equality. But, under conditions as they are at present, most women have very hittle property when they marry, have very little opportunity to acquire property, and as a rule give up that opportunity in order to maintain a home for the family. Unless, therefore, the wife has an interest in the gains of the husband from his business she has in most cases little chance to acquire any property which she can call her own. The husband must provide the necessities of life, but beyond that anything that the wife gets comes as a favor and not as a right. Her interest is termed a community interest implying that there is a partnership, but it is a partnership which only commences on its termination. ${ }^{22}$ The only way in which

apparel of the minor children or of the spouse not making the sale or encumbrance.

"Both husband and wife must join in the instrument by which community real property, or any interest therein, is leased, sold, transferred, conveyed or encumbered.

"Sec. 3. Section one hundred sixty-seven of the Civil Code is hereby repealed.

"Sec. 4. Section one hundred seventy-two $a$ of the Civil Code is hereby repealed."

"Section 1. Section one thousand four hundred one of the Civil Code is hereby amended to read as follows:

"1401. Upon the death of either husband or wife, the community property is distributed as follows, to wit: Subject first to the law regarding homesteads, to the family allowance, to the payment of debts lawfully chargeable against the community property and to the expenses of admimistration, one-half of the community property goes to the surviving spouse, and the other half is subject to the testamentary disposition of the deceased spouse. In the absence of such disposition by the deceased spouse, the entire community property goes, without administration, to the surviving spouse. Unless a will of the deceased spouse making such disposition is filed for probate within ninety days from and after his or her death, it shall be conclusively presumed that such deceased spouse elected not to exercise such right of testamentary disposition.

"Sec. 2. Section one thousand four hundred two of the Civil Code is hereby repealed."

22 Garrozi v. Dastas (1907) 204 U. S. 64, 51 L. Ed. 369. 
the wife can enjoy the so-called community property as a matter of right before the death of her husband is to get a divorce.

What then are the objections to a real partnership giving the wife an equal share in the management and control while the partnership continues and an equal interest on dissolution by death? The objections to the proposed bills fall into two classes; the first, the objections to the bills as drafted; these may be cured by amendment. The second objections are inherent in the changes proposed. Objections not likely to arise in practice will not be discussed. It is possible to put a multitude of supposititious cases that have not been provided for, but the same thing can be done with the present law.

Taking up the first class, the principal objections that occur are the following:

1. It is provided that both husband and wife must join in a conveyance of the community property. There is no protection, however, afforded to a bona fide purchaser who might examine the records and find the title vested in a certain man; this man might conceal the fact of his marriage and it might be impossible by any reasonable diligence to ascertain that he was married. Nevertheless the wife could claim her community interest even against the purchaser. This objection could and should be obviated by requiring a recordation of the marriage certificate in the county where the land is situated. Incidentally it should be noted that the proposed amendment continues the language of the 1917 amendment to section 172 of the Civil Code. It requires both husband and wife to join in the instrument by which community real property is leased, etc. This would seem to prevent either spouse from acting by attorney. In other words, for example, if the husband were about to leave the state for a prolonged absence, and desired by power of attorney to enable his wife to sell or mortgage the community real estate in his absence, this could not be accomplished. Both husband and wife must sign the same instrument. Does not this go farther than the protection of the wife requires?

2. The objection is made that section 1469 of the Code of Civil Procedure, providing for administration of estates not exceeding $\$ 1500$ in value, is repealed. The simple procedure of section 1469 and the limited exemption from the claims of creditors thereby afforded seems desirable. Also, if the husband is to receive the community on the death of the wife by suc- 
cession, section 1469 should be amended to apply in his favor also.

3. It is difficult to ascertain just what rights creditors would have under the proposed bill. According to the language, each spouse is presumed to be the agent of the other for the purpose of managing, controlling, conveying or encumbering community personal property which is in his or her inmediate possession or control. But how does this affect ordinary contracts? Suppose either spouse makes a contract to purchase real estate or shares of stock in a corporation. Suppose either spouse goes on a contractor's bond or commits a tort. Assume that in any of the above cases a liability is incurred and judgment obtained against the spouse. What property can be seized on execution? Clearly the separate property of the spouse incurring the liability, and probably, although this is not so clear, not the separate property of the spouse who did not incur the liability. But how about the community property? Is it liable at all, and if so should the spouse not incurring the liability have a claim against the community property to the extent of half the loss? If the measure means that the community should be liable for the debts of each spouse this should be clearly expressed. If the liability of the community is to be limited the linitation should be defined so that creditors may know what property may be taken in satisfaction of a judgment.

4. There is also danger that the separate property of each spouse may be jeopardized by the other. The proposed amendment to section 172 of the Civil Code provides: "Each spouse is presumed to be the agent of the other for the purpose of managing, etc., personal property which is in his or her immediate possession or control." It might be held that within the scope of this limited agency, each spouse, as agent, might bind the other spouse as principal and thereby subject the separate property of the other to liability.

5. Under the proposed law, on the death of one of the spouses intestate, the entire community vests in the survivor without administration. It is open to question whether it is wise to dispense with probate proceedings. It is true that there is no administration at present on the community when the wife dies, but the wife has no creditors who have any claim agamst the community. Under the proposed legislation, it is true, that there may be creditors of the wife who have claims against the community property, but they will not as a rule be 
numerous. With the husband the case is entirely different. On his death all his obligations are claims against the community. These clains must be established and paid. If disputed an action must be brought. Where there is no administration this action would probably have to be brought against the wife to establish a claim on the community property in her hands. Each action would have to be brought separately. No limit of time other than the general Statute of Limitations is prescribed for bringing such actions. There would be no segregation of the property and no inventory. It is worth consideration whether the simplicity and cheapness in dispensing with administration are not illusory, and whether the rights of creditors and of the widow would not be better protected by the orderly procedure in rem of administration. Furthermore, if there were administration, it would not be necessary to have a conclusive presumption that there is no will, if one is not filed within ninety days after death. That is a rather dangerous provision in the proposed law. It offers a motive strong for the concealment of wills.

Coming to the objections which no amendment can cure and that are inherent in the proposal, the following have been suggested:

1. The sentimental objection that the inarriage relation is imperiled. This objection has been made to every change in the property relations of husband and wife. The fears expressed by a learned judge, when the courts of equity created separate property for a married woman are no less unfounded than the gloomy forebodings indulged in in regard to the pending legislation.

"In the language of $\mathrm{Sir}$ Wm. Blackstone: 'By marriage, the husband and wife are one person in law: that is, the very being or legal existence of the woman is suspended during the marriage, or at least is incorporated and consolidated into that of the husband; under whose wing, protection and cover she performs everything.' I confess that I love and venerate the primeval notion of that mystical and hallowed union of husband and wife: when 'they twain became one flesh;' when they 'forsook father and mother, and clave to each other' with unreserved confidence. Marriage, in that old fashioned sense, is the purest source of domestic joys, and the firm foundation of social order.

"I bow to the rule, as I find it established; but I lament the complicated and artificial anomalies in the relations of domestic life, which have grown and are still growing out of the practice of marriage settlements. They give to the 
wife the amphibious character of a feme covert and a feme sole. I view it as an adulteration of that holy union-as a divorce, pro tanto, of the marriage contract. A wife, in the 'independent enjoyment of her separate estate,' armed with distrust of her husband, and shutting out his affections and confidence, by refusing to give her own in mutual exchange, is an object of compassion and disgust. Legal chastity cannot be denied to her; but there is danger that the sacred institution of marriage may degenerate into mere form. It is sometimes, in practice, little more than legalized prostitution; and the parties seem to have no higher objects than sexual intercourse and the sanction of legitimacy for their offspring. If, in the rapid progress of refinement in civilization, it shall be thought expedient to go one step further, and to allow the wife, by ante-nuptial contract, to stipulate for an exemption from personal control over her by the husband, then the quasi divorce would be extended one degree further, so as to confer on her the independent enjoyment of the rights and privileges of a kept mistress. But she would have little claim, indeed, to the endearing appellation and character of a wife.

"The new rule, introduced by $\mathrm{Sir}$ R. P. Arden and Lord Loughborough and which has been adopted by His Honor, the Chancellor, in this case, will, I think, tend to sever, in some degree, the marriage union; because it not only renders the wife independent of her husband, as to her fortune, but bars him from participation of it, by new and increased impedinients; as if he were presumed to be her worst enemy. Now, if matrimony is not safe and desirable, without these tranimels, and fences, and reservations and restrictions, I say, marry not at all!"23

2. Tremendous injury to the commercial and financial development of California: Business men are in the habit of coming before the legislature when any important matter affecting business is at issue and prophesying the disastrous results which will follow from its enactment. At each session we have seen such legislation passed and business has gone on as ustal. We must therefore turn our attention not to general charges that credit will be destroyed, but look to the particular features of the bill which nay have that tendency.

3. The proposed legislation gives the wife the powers of a partner in the business of her husband, whereas in most cases she is entirely lacking in business experience and ability. To the marital union is added a comnercial partnership. The power

${ }_{23}$ Mr. Justice Platt in Jaques v. Trustees of the Methodist Episcopal Church in New York, et al. (1820) 17 Johns. 548, p. 581 (6 N. Y. C. 
thus given includes necessarily the power to injure the community property. It is highly improbable, however, that this power will be exercised very often for the destruction of the community property. (a) Business after the passage of this law will in the great majority of cases go on just as it has before, the wives who have been satisfied to allow their husbands to run the business will continue to be satisfied. (b) For a long time to come few men will care to rely on the power of a married woman as agent of the community, because the proposed legislation could not have a retroactive effect. It could not therefore affect community property previously acquired, so that anyone who buys personal property from a married woman, relying upon her possession as agent of the community, will be taking the risk that the property had been acquired prior to the passage of the act. ${ }^{24}$ It should be noted, however, that the proposed amendment to section 1401 of the Civil Code, prescribing the succession to the community property, affects all community property whenever acquired.

4. A more serious danger is the one that is involved in the bill giving the wife equal rights over the community property with the husband on dissolution by death. As the law stands at present, on the death of the wife the entire community property goes to the husband without administration. On the death of the husband only half the community property goes to the wife; the rest is subject to the husband's testamentary disposition, or, in case of intestacy, goes to the husband's heirs. Under the proposed legislation on the death of either, the entire community goes to the survivor unless the decedent has exercised by will the power to dispose of one half. It is claimed that this will be disastrous to credit, because it will result in the husband's business being broken up on the death of the wife in case she makes a will and thereby deprives her husband of half of his business. To this it may be said: (a) Few banks lend on the good will of a business; they generally provide for sufficient security to protect them if the business should be suddenly dissolved. (b) In many cases the wife leaves the property to the husband anyway or dies intestate. (c) In other cases the property is willed to the children in whom the father is

L. 464.)

24 Spreckels v. Spreckels (1897) 116 Cal. 339, 48 Pac. 228, 36 L. R. A. 697, 58 Am. St. Rep. 170. But see Arnett v. Reade (1911) 220 U. S. 311, 55 L. Ed. 477. 
equally interested, and with whom he would be willing to act in the carrying on of the business. (d) Any man who fears that his business may be broken up by his wife's interference during life or by her testamentary disposition on her death may make a contract with the wife to guard against such a contingency. (e) In large concerns the business is usually incorporated; all that would pass on the death of the wife would be shares of stock; the business would go on just the same.

It is apparent, however, that the proposed legislation does give to the wife, who is usually inexperienced in business, and seldom has the skill and capacity prerequisite for a business partner, the power to destroy the business during her lifetime, and on her death to compel its dissolution by willing away half of it to persons adverse in interest to her husband. This latter danger is especially to be feared where the husband is carrying on a small business on which his living depends, and where it would be impossible to make a livelihood unless he owned the whole. If the proposed legislation passes it will be necessary for a man to be as careful in choosing a wife as in selecting a business partner. There is also a danger to the business partner of a married man, in case the married partner's wife dies. Careful lawyers in drawing partnership articles will doubtless require some renunciation by the wives of their claims, and will provide for some preferred right in the partners to purchase the interest of the wife's legatee. In time there may develop some statutory system whereby the survivor of the community will carry on the business as trustee for himself and the legatees of the deceased spouse.

On the whole the present California law is more favorable to the wife than the other systems considered. It is more favorable than the English in that the wife after the death of the husband receives one half the community. There is a slight disadvantage in that the earnings of the wife in California are subject to the husband's control while she lives with him. The present California law has the same advantage over the prevailing German law that it has over the English. The French law gives the wife a right to her share of the cominunity on dissolution and includes more than the California law allows, for by judicial construction, the wife is allowed to will her share of the community where she does not survive her hus- 
band, which she can not do in California today. ${ }^{25}$ But on the other hand the husband has control in France not only of the community but also of the wife's separate property.

Every effort should be nrade to present the bills in the best possible form. The passage of such iniportant measures affecting the social and family relations should not be influenced by legal technicalities. The fundamental question is whether there is justice in the contention that a married woman is entitled to have an equal control of the property acquired by the business exertions of the spouses during marriage. If this claim is just, is the incidental disturbance to business practice sufficiently serious to make it inexpedient?

A. M. Kidd.

Berkeley, California.

25 Professor Freund notes this as a striking example of the judicial development of a code provision by analogy. 65 University of Pennsylvania Law Review, 229. 